\title{
Antibacterial Activity of Pinus pinaster Bark Extract and its Components Against Multidrug-resistant Clinical Isolates of Acinetobacter baumannii
}

\author{
Mirna Ćurković-Perica, ${ }^{\mathrm{a}, *}$ Jasna Hrenović, ${ }^{\mathrm{a}}$ Nuša Kugler, ${ }^{\mathrm{b}}$ Ivana Goić-Barišić, ${ }^{\mathrm{c}}$ and Mirta Tkalec ${ }^{\mathrm{a}}$ \\ ${ }^{a}$ University of Zagreb, Faculty of Science, Department of Biology, Division of Microbiology, Zagreb, Croatia \\ ${ }^{\mathrm{b}} Z$ Zel-en razvojni center energetike, d.o.o, Sevnica, Slovenia \\ ${ }^{c}$ University Hospital Centre Split and University of Split School of Medicine, Department of Clinical Microbiology,
}

Split, Croatia

\begin{abstract}
The aim of this research was to test the antibacterial activity of Pinus pinaster aqueous bark extract (PABE) and its basic components against multidrug-resistant isolates of Acinetobacter baumannii belonging to European clone I and II, isolated previously from the clinical outbreaks. The minimum bactericidal concentration of PABE against both clones of $A$. baumannii was $200 \mathrm{mg} \mathrm{m}^{-1}$, while lower concentrations showed high antibacterial activity. After $24 \mathrm{~h}$ of treatment with 100,50 or $10 \mathrm{mg} \mathrm{m}^{-1}$ of extract, the reduction in the number of $A$. baumannii isolates belonging to European clone I and II was $85.8 \pm 2.5 \%, 78.5 \pm 1.1 \%, 66.3 \pm 2.5 \%$ and $90.2 \pm 1.7 \%, 78.6 \pm 1.2 \%, 69.8 \pm 0.7 \%$, respectively. Several basic components: caffeic acid, catechin, epicatechin, gallic acid and vanillin, detected in the extract by high performance liquid chromatography, contributed to the antibacterial activity of the extract against both clones of $A$. baumannii. However, the antibacterial activity of extract was higher than that of each tested basic component suggesting that proanthocyanidins, which were present in quite a large amount in the extract, might have also contributed to the activity of the extract. Antibacterial activity of PABE against A. baumannii reveals that complex and inexpensive natural product might be useful in combat against naturally competent bacteria that easily acquire resistance against antibiotics.
\end{abstract}

Keywords: antimicrobials, aqueous extract, bacteria, multidrug-resistant pathogens, natural compounds

\section{INTRODUCTION}

Bark extracts of $P$. pinaster (PBEs) have a long history of ethnomedicinal use. ${ }^{1}$ As a mixture of a large variety of substances, PBEs are reported to exhibit a wide range of biological activities, including antioxidative, antiinflamatory, antitumor, antiatherogenic, antiviral, antimicrobial, etc. $^{2}$ In papers published thus far, different extraction procedures, using different solvents were applied, affecting the composition of extracts and biological activity.

Species of the genus Acinetobacter, like A. baumannii are naturally competent ${ }^{3}$ and easily acquire DNA from the environment/other species. Therefore, it is not surprising that Acinetobacter spp. displays mechanisms of resistance to all existing antibiotic classes as well as a prodigious capacity to acquire new determinants of resistance. ${ }^{4}$ A. baumannii is a nonfermentative, Gramnegative, nonmotile, oxidase-negative coccobacillus which is found in many health care environments ${ }^{5}$ and is a very effective human colonizer. This species emerged over the last decade as a leading cause of hospital-acquired infec- tions; there are numerous reports of multidrug-resistant (MDR) A. baumannii from hospitals around the world ${ }^{6}$ including Croatia. ${ }^{7,8}$ Problems caused by $A$. baumannii in the hospital setting are emphasized by high degree of resistance to drying and disinfectants, leading to longterm persistence and the occurrence of outbreaks in the hospital environment. ${ }^{6}$ Global outbreaks of infections caused by $A$. baumannii are also frequent. ${ }^{4}$

Current concerns regarding inefficiency of antibiotics or deleterious effects of synthetic chemicals used for medical purposes have encouraged a worldwide research on natural products potentially useful in development of alternative treatments for common and emerging pathogens. Research on natural products represents convenient strategy to find extracts and bioactive compounds, based on which new, effective and less expensive treatments can be applied. ${ }^{9}$ The aim of this study was to determine the antibacterial and bactericidal activity of $P$. pinaster aqueous bark extract (PABE) and its components against MDR A. baumannii isolated from the clinical outbreaks.

\footnotetext{
* Author to whom correspondence should be addressed. (E-mail: mirna.curkovic-perica@biol.pmf.hr)
} 


\section{EXPERIMENTAL}

\section{Plant Material and Preparation of Extracts}

In Croatia Pinus pinaster is mostly planted in coastal region. For this research bark was collected from 15 trees growing on the island of Rab. Bark samples from 15 trees were randomly pooled to form 3 samples (barks collected from 5 trees in each sample), air dried at $50-55{ }^{\circ} \mathrm{C}$ for eight days to constant weight and grinded to pieces (fraction $<1 \mathrm{~mm}$ ) using Colortronic mill. Grinded bark $(100 \mathrm{~g})$ was extracted with $500 \mathrm{ml}$ of water at $100{ }^{\circ} \mathrm{C}$ for 30 minutes. The aqueous extract was collected and grinded bark was once again extracted with $500 \mathrm{ml}$ of fresh water at $100{ }^{\circ} \mathrm{C}$ for 30 minutes. The first and second extract were pooled and drypowdered extract was prepared from aqueous extract by spray-drying at $200{ }^{\circ} \mathrm{C}$. From $100 \mathrm{~g}$ of grinded bark approximately $10 \mathrm{~g}$ of powdered extract was obtained. For treatment of bacteria dry-powdered extract was solved in sterile distilled water.

\section{HPLC Analysis of Pinus pinaster Aqueous Bark Extract (PABE)}

The following substances were detected and quantified: caffeic acid (cas: 331-39-5), catechin (cas: 225937-10-0), epicatechin (cas: 490-46-0), ferulic acid (cas: 537-98-4), gallic acid (cas: 149-91-7), taxifolin (cas: 24198-97-8) and vanillin (cas: 121-33-5). Authentic standards were purchased from Fluka (Germany) and Sigma-Aldrich (Germany). High performance liquid chromatography analysis (HPLC) system (Shimadzu, SIL-20AC XR) equipped with a quaternary pump, multi-wave UV/Vis detector, autosampler, fraction collector and Kinetex $2.6 \mathrm{u}$ C18 100A column; $(100 \times 4,60 \mathrm{~mm}$, Phenomenex $)$ was used for all analyses. Absorbance was measured from $200 \mathrm{~nm}$ to $400 \mathrm{~nm}$. The injection volume was $20 \mu \mathrm{l}$ and the flow rate $1.0 \mathrm{ml} \mathrm{min}^{-1}$ from $0-29$ minute and $38-45$ minute, and $1.5 \mathrm{ml} \mathrm{min}^{-1}$ from $29-38$ minute, at $30{ }^{\circ} \mathrm{C}$. Elution profile consisted of solvent A (vol. ratio: deionised $\mathrm{H}_{2} \mathrm{O}: \mathrm{H}_{3} \mathrm{PO}_{4}=999: 1$ ) and solvent $\mathrm{B}$ (vol. ratio: methanol : $\left.\mathrm{H}_{3} \mathrm{PO}_{4}=999: 1\right)$. The solvent composition (A/B) changed according to the following gradient: $97 / 3$ at $0 \mathrm{~min}, 97 / 3$ at $2 \mathrm{~min}, 85 / 15$ at $6 \mathrm{~min}, 84 / 16 / 0$ at $15 \mathrm{~min}, 82 / 18$ at $29 \mathrm{~min}, 47 / 53$ at $30 \mathrm{~min}, 10 / 90$ at 31 $\mathrm{min}, 10 / 90$ at $38 \mathrm{~min}$ and finally $97 / 3$ at $39 \mathrm{~min}$. Concentrations of tested compounds were determined, based on the chromatographic data of the standards. The calibration curves (peak area $v s$. concentration) for individual compounds were obtained for a wide concentration range. Analyses of each extract were done in triplicates. The concentration of each substance was expressed in $\mathrm{mg} \mathrm{g}^{-1}$ of dry extract. Retention times were: $3.74 \mathrm{~min}$ for gallic acid; $10.722 \mathrm{~min}$ for catechin; $13.272 \mathrm{~min}$ for caffeic acid; 14.385 min for vanillin; 17.457 min for epicatechin; $20.213 \mathrm{~min}$ for p-cumaric acid; $25.125 \mathrm{~min}$ for ferulic acid; $26.074 \mathrm{~min}$ for taxifolin.

\section{Determination of Proanthocyanidins (PA) Content}

The proanthocyanidins were determined by hydrochloric acid-butanol method. ${ }^{10}$ Ten milligram of pine bark extract was dissolved in $10 \mathrm{ml}$ of water. To $0.20 \mathrm{ml}$ of this solution $3 \mathrm{ml}$ of a $95 \%$ solution of $n$-butanol $/ \mathrm{HCl}$ $(95 / 5 ; v / v)$ was added, followed by addition of $0.1 \mathrm{ml}$ of a $1.4 \%(w / v) \mathrm{Fe}\left(\mathrm{SO}_{4}\right) \times 7 \mathrm{H}_{2} \mathrm{O}$ in $2 \mathrm{M} \mathrm{HCl}$. The tubes were incubated for $40 \mathrm{~min}$ at $95{ }^{\circ} \mathrm{C}$. After incubation, the samples were cooled and analyzed by measuring absorbance at $550 \mathrm{~nm}$. Cyanidin chloride (Sigma-Aldrich, Germany) was used as a standard. The final PA in pine bark extracts was expressed on a dry basis (mg/gDW) and data were shown as a mean value of three biological and three technical replicates $\pm \mathrm{SE}$.

\section{Bacterial Strains}

Antibacterial activity of PABE against two different isolates of $A$. baumannii with affiliation to European clone I (EU I) and II (EU II) was tested and compared. Clinical isolates of $A$. baumannii were collected during two different outbreaks, first from 2002-2007 (EU I) and second from 2009-2010 (EU II) in Clinical Hospital Center Split, Croatia, ${ }^{7,8}$ a referral hospital for a wide area of southern Croatia. Isolation of $A$. baumannii was performed on blood agar plates (Bio Rad). Initial identification was made using the ATB 32GN and Vitek 2 systems (bioMerieux, Marcy-l'Etoile, France) according to Clinical and Laboratory Standards Institute recommendations, CLSI. ${ }^{11}$ Susceptibility to $\beta$-lactams (ceftazidime, ceftriaxone, cefepime, imipenem, meropenem), $\beta$-lactam/ $\beta$-lactamase inhibitor combinations (ampicillin/sulbactam, piperacillin/tazobactam), aminoglycosides (amikacin, gentamicin) and fluoroquinolones (ciprofloxacin) was determined by disc-diffusion tests, and susceptibility to colistin by E-tests (AB Biodisk, Solna, Sweden). MICs were determined by broth microdilution according to CLSI. ${ }^{11}$ Isolate from EU clone II was resistant to all antimicrobials (imipenem MIC $64 \mu \mathrm{g} \mathrm{ml}^{-1}$, meropenem $128 \mu \mathrm{g} \mathrm{ml}^{-1}$, amikacin $64 \mu \mathrm{g} \mathrm{ml}^{-1}$, gentamicin 64 $\mu \mathrm{g} \mathrm{ml}^{-1}$, ceftazidime $256 \mu \mathrm{g} \mathrm{ml}^{-1}$, cefepime $128 \mu \mathrm{g} \mathrm{ml}^{-1}$, ciprofloxacin $32 \mu \mathrm{g} \mathrm{ml^{-1 }}$, piperacillin/tazobactam 128 $\mu \mathrm{g} \mathrm{m} \mathrm{m}^{-1}$ and ceftriaxone $256 \mu \mathrm{g} \mathrm{ml}^{-1}$ ) except colistin (MIC: $0.5 \mathrm{mg} \mathrm{ml}^{-1}$ ) and ampicillin/sulbactam (MIC: 1 $\mathrm{mg} \mathrm{ml}^{-1}$ ). Isolate from EU clone I had lower minimum inhibitory concentrations (MIC) for carbapenems (imipenem $6 \mathrm{mg} \mathrm{ml}^{-1}$, meropenem $16 \mathrm{mg} \mathrm{ml}^{-1}$ ) than isolate belonging to EU clone II (imipenem and meropenem $\left.\geq 64 \mathrm{mg} \mathrm{ml}^{-1}\right) .{ }^{12}$ The mechanisms of carbapenem resistance were described previously., 


\section{Antibacterial Activity Tests}

The antibacterial activities of PABE against isolates of $A$. baumannii belonging to the EU clone I and II were tested according to the microdilution method, following the CLSI recommendations. ${ }^{11}$ The bacteria were pre-grown on nutrient agar (Biolife, Italy) for $16 \mathrm{~h}$ at $36.0 \pm 0.1^{\circ} \mathrm{C}$ to obtain the cultures in log phase of growth. The bacterial biomass was then suspended in the nutrient broth (Biolife, Italy). For the experiments with powdered extract, $200,100,50,10$ or $1 \mathrm{mg}$ of extract was added into $0.5 \mathrm{ml}$ of sterile deionised water and vigorously shaken (40 $\mathrm{Hz} / 10 \mathrm{~min}$, Kartell TK3S). A $0.5 \mathrm{ml}$ of bacterial suspension was added in the tubes, which resulted in following concentrations of powdered extract: 200,100,50,10 or 1 $\mathrm{mg} \mathrm{ml}^{-1}$. The tubes which served as the positive control contained $0.5 \mathrm{ml}$ of bacterial suspension and $0.5 \mathrm{ml}$ of sterile deionised water. Both experiments were set in triplicate. The tubes were incubated in a dark during $24 \mathrm{~h}$ at $36.0 \pm 0.1{ }^{\circ} \mathrm{C}$ with shaking at $120 \mathrm{rpm}$ to assure the complete mixing. To confirm the antibacterial activity of basic components of extract, the experiments with pure caffeic acid, catechin, epicatechin, ferulic acid, gallic acid, taxifolin and vanillin solutions in $2 \%$ ethanol were set up in triplicate. The tested concentrations of basic components were equivalent to those contained in 200 $\mathrm{mg} \mathrm{ml}^{-1}$ of powdered extract. The positive controls were set up without and with $2 \%$ of ethanol, which showed no difference in the number of bacteria (data not shown).

The number of viable cells was determined at the beginning of experiment and after $24 \mathrm{~h}$ of treatment. Tubes were vigorously shaken and $0.1 \mathrm{ml}$ of sample was plated (spread plate method) directly onto the nutrient agar, while another sample was serially diluted $\left(10^{-1}\right.$ to $10^{-8}$ ) and inoculated onto the nutrient agar plates in triplicate. The inoculated plates were incubated at 36.0 $\pm 0.1{ }^{\circ} \mathrm{C}$ for $24 \mathrm{~h}$. After the incubation period, the bacterial colonies were counted and the number of viable cells was reported as Colony forming units (CFU) $\mathrm{ml}^{-1}$. The numbers of CFU were logarithmically transformed. The antibacterial activity of the extract, each compound and mixture of compounds (caffeic acid, catechin, epicatechin, ferulic acid, gallic acid, taxifolin and vanillin) was expressed as the reduction of $\log \mathrm{CFU}$ and as the percent reduction of log CFU as compared to the corresponding control. The minimum bactericidal concentration (MBC) values were determined after $24 \mathrm{~h}$ of experiments according to the CLSI directions. ${ }^{11}$ The minimum inhibitory concentration (MIC) was not determined due to the turbidity and colour of extracts. The comparisons between the numbers of $\log \mathrm{CFU}$ were done using the ANOVA and subsequently the post-hoc Duncan test was performed for the calculations concerning pair-wise comparisons. Statistical decisions were made at a significance level of $\mathrm{p}<0.05$.

\section{RESULTS AND DISCUSSION}

Concentrations of basic substances (determined by HPLC) as well as proanthocyanidins were expressed as $\mathrm{mg} \mathrm{g}^{-1}$ of spray-dried powdered PABE (Table 1). Statistically significant differences in the concentrations of basic compounds and proanthocyanidins between extracts from 3 pooled samples (barks collected from 5 trees in each sample) were not determined, and therefore the extracts were pooled for further experiments/ treatments.

Antibacterial activities of PABE against isolates of A. baumannii belonging to EU clone I and II are shown in Table 2. The extract showed antibacterial activity with $\mathrm{MBC}$ of $200 \mathrm{mg} \mathrm{ml}^{-1}$ against both clones.

To elucidate which basic components contribute to the bactericidal activity of powdered extract at concentration of $200 \mathrm{mg} \mathrm{ml}^{-1}$, experiments with pure solutions of components were performed (Table 3 ). For clone I caffeic acid, catechin, epicatechin, ferulic acid, gallic acid and vanillin resulted in statistically significant reduction of $\log \mathrm{CFU}$ as compared to corresponding control, but the reduction of $\log$ CFU was generally low (0.4-0.9 log CFU reduction). The antibacterial activity of basic components against clone II (Table 3) was similar to those against clone I, except that the ferulic acid had no antibacterial activity against clone II. When basic substances were tested together against two clones of $A$. baumannii, the reductions of $\log$ CFU were 36.9 and $23.5 \%$ for clone I and II, respectively. These results suggest that besides tested substances, some other substances such as proanthocyanidins, which were present in quite a large amount in the extract (Table 1), might have contributed to the antibacterial activity of extract, too.

Table 1. Concentrations of basic substances and proanthocyanidins in Pinus pinaster aqueous bark extract (PABE) expressed as $\mathrm{mg} \mathrm{g}^{-1}$ of spray-dried powdered PABE. Data shown are mean values of three biological and three technical replicates $\pm \mathrm{SE}$.

\begin{tabular}{cc}
\hline Basic component & $\begin{array}{c}\text { Concentration } / \mathrm{mg} \mathrm{g}^{-1} \text { in } \\
\text { P. pinaster } \text { bark extract (PABE) }\end{array}$ \\
\hline caffeic acid & $0.5 \pm 0.03$ \\
catechin & $5.5 \pm 0.7$ \\
epicatechin & $0.7 \pm 0.02$ \\
ferulic acid & $1.13 \pm 0.16$ \\
gallic acid & $0.27 \pm 0.03$ \\
taxifolin & $2.4 \pm 0.32$ \\
vanillin & $0.42 \pm 0.05$ \\
proanthocyanidins & $38.1 \pm 2.8$ \\
\hline
\end{tabular}


Table 2. Reduction in the number of $A$. baumannii isolates belonging to European clone I and II after $24 \mathrm{~h}$ of treatment with Pinus pinaster aqueous bark extract as compared to the corresponding control. co A. baumannii clone $\mathrm{I}\left(10^{7} \mathrm{CFU} \mathrm{ml}^{-1}\right)=2.93 \pm$ $0.57 ; c_{0}$ A. baumannii clone II $\left(10^{7} \mathrm{CFU} \mathrm{ml}^{-1}\right)=1.54 \pm 0.26$. Bactericidal activity was obtained at $200 \mathrm{mg} \mathrm{ml}^{-1}$, and antibacterial activity at $10 \mathrm{mg} \mathrm{ml}^{-1}$. Data shown are mean values of three biological and three technical replicates $\pm \mathrm{SE}$.

\begin{tabular}{ccccc}
\hline $\begin{array}{c}\text { Pine extract / } \\
\mathrm{mg} \mathrm{ml}^{-1}\end{array}$ & \multicolumn{2}{c}{ A. baumannii clone I } & \multicolumn{2}{c}{ A. baumannii clone II } \\
\hline 200 & Reduction $\log$ CFU & Reduction / \% & Reduction log CFU & Reduction / \% \\
\hline 100 & $8.3 \pm 0.1^{\text {(a) }}$ & $100.0 \pm 0.0$ & $8.9 \pm 0.1^{\text {(a) }}$ & $100.0 \pm 0.0$ \\
50 & $7.1 \pm 0.1^{\text {(a) }}$ & $85.8 \pm 2.5$ & $8.0 \pm 0.2^{\text {(a) }}$ & $90.2 \pm 1.7$ \\
10 & $6.5 \pm 0.1^{\text {(a) }}$ & $78.5 \pm 1.1$ & $7.0 \pm 0.1^{\text {(a) }}$ & $78.6 \pm 1.2$ \\
1 & $6.0 \pm 0.1^{\text {(a) }}$ & $66.3 \pm 2.5$ & $6.4 \pm 0.1^{\text {(a) }}$ & $69.8 \pm 0.7$ \\
\hline
\end{tabular}

(a) significant reduction as compared to control.

Several research groups published the results on antimicrobial activity of PBEs. As opposed to simple aqueous extract (PABE) which was used in this research, in those researches mostly Pycnogenol ${ }^{\circledR}$ - commercial water/ethanol extract was tested and it was shown that $250 \mu \mathrm{g} \mathrm{ml}^{-1}$ of Pycnogenol ${ }^{\circledR}$ counteracted the growth of several tested Gram-positive and Gramnegative bacteria, ${ }^{13}$ inhibited growth of Helicobacter pylori in suspension $\left(12.5 \mu \mathrm{g} \mathrm{ml}^{-1}\right)$, while in ten times higher concentration reduced the adherence of the bacterium to gastric cells. ${ }^{14}$ However its efficiency against A. baumannii was not tested. Grimm et al. ${ }^{15,16}$ showed that substances which are basic components of PBE are quickly absorbed after oral ingestion and their distribution in the body tissues is fast. Fourteen hours after volunteers were given $300 \mathrm{mg}$ or $200 \mathrm{mg}$ of PBE, fifteen compounds from PBE were detected in the their plasma. ${ }^{15,16}$ Maximum concentrations of four identified compounds in the plasma; catechin, caffeic acid, ferulic acid and taxifolin were $107 \mathrm{ng} \mathrm{ml}^{-1}, 17 \mathrm{ng} \mathrm{ml}^{-1}$, $15 \mathrm{ng} \mathrm{ml}^{-1}$ and $33 \mathrm{ng} \mathrm{ml}^{-1}$, respectively. Of those four substances, caffeic acid and catechin revealed antibacte- rial activity against $A$. baumannii clones in our research, but epicatechin, gallic acid and vanillin also contributed to the activity of PABE against both clones of $\mathrm{A}$. baumanii, while ferulic acid slightly contributed to the activity of PABE against EU clone I. The above mentioned substances are known to possess antimicrobial activity against different pathogens. Vanillin is proved to express antifungal activity ${ }^{17}$ and antibacterial activity against Cronobacter species; ${ }^{18,19}$ catechin was effective against pathogenic bacteria, Escherichia coli O157:H7, Pseudomonas aeruginosa and the food spoilage fungus Penicillium chrysogenum ${ }^{20,21}$ and, it also showed synergistic antibacterial effect with antibiotics. ${ }^{22}$ Furthermore, the combination of catechin and epicatechin gallate potentiated the activity of beta-lactam antibiotics against methicillin-resistant Staphylococcus aureus. ${ }^{23}$ Furthermore, epicatechin showed synergistic effect with the aflavin against clinical isolates of $A$. baumannii and Stenotrophomonas maltophilia. ${ }^{24}$ Caffeic acid is also known to exhibit antimicrobial activity, however its concentration in PABE was $0.05 \%$ making it even less concentrated in solution which was applied to $A$. baumannii,

Table 3. Reduction in the number of $A$. baumannii isolates belonging to European clone I and II after $24 \mathrm{~h}$ of treatment with basic components of Pinus pinaster bark extract (in concentration contained in $200 \mathrm{mg} \mathrm{ml}^{-1}$ of powdered extract) as compared to the corresponding control. $c_{0}$ A. baumannii clone $\mathrm{I}\left(10^{7} \mathrm{CFU} \mathrm{ml}^{-1}\right)=7.35 \pm 0.92 ; c_{0}$ A. baumannii clone $\mathrm{II}\left(10^{7} \mathrm{CFU} \mathrm{ml}^{-1}\right)=4.90 \pm$ 0.14. Data shown are mean values of three biological and three technical replicates $\pm \mathrm{SE}$.

\begin{tabular}{|c|c|c|c|c|c|}
\hline \multirow{2}{*}{ Component } & \multirow{2}{*}{$\begin{array}{c}\text { Concentration / } \\
\mu \mathrm{g} \mathrm{ml}^{-1}\end{array}$} & \multicolumn{2}{|c|}{ A. baumannii clone I } & \multicolumn{2}{|c|}{ A. baumannii clone II } \\
\hline & & Reduction $\log$ CFU & Reduction / \% & Reduction $\log$ CFU & Reduction / \% \\
\hline Caffeic acid & 100 & $0.5 \pm 0.0^{(\mathrm{a})}$ & $5.6 \pm 0.5$ & $0.3 \pm 0.1^{(\mathrm{a})}$ & $3.9 \pm 1.0$ \\
\hline Catechin & 110 & $0.9 \pm 0.0^{(\mathrm{a})}$ & $9.7 \pm 0.1$ & $0.1 \pm 0.0^{(\mathrm{a})}$ & $1.2 \pm 0.1$ \\
\hline Epicatechin & 140 & $0.4 \pm 0.0^{(\mathrm{a})}$ & $4.5 \pm 0.1$ & $0.3 \pm 0.0^{(\mathrm{a})}$ & $3.3 \pm 0.0$ \\
\hline Ferulic acid & 226 & $0.6 \pm 0.0^{(a)}$ & $6.2 \pm 0.4$ & $0.0 \pm 0.0$ & $-0.1 \pm 0.1$ \\
\hline Gallic acid & 54 & $0.4 \pm 0.0^{(\mathrm{a})}$ & $4.3 \pm 0.3$ & $0.8 \pm 0.0^{(\mathrm{a})}$ & $8.7 \pm 0.2$ \\
\hline Taxifolin & 400 & $0.1 \pm 0.0$ & $0.9 \pm 0.2$ & $0.0 \pm 0.0$ & $0.0 \pm 0.1$ \\
\hline Vanillin & 84 & $0.5 \pm 0.0^{(\mathrm{a})}$ & $6.2 \pm 0.1$ & $0.3 \pm 0.0^{(\mathrm{a})}$ & $3.4 \pm 0.1$ \\
\hline All components & & $3.4 \pm 0.0^{(\mathrm{a})}$ & $36.9 \pm 0.2$ & $2.2 \pm 0.0^{(\mathrm{a})}$ & $23.5 \pm 0.0$ \\
\hline
\end{tabular}

(a) significantly different as compared to control 
and it was reported previously that concentrations higher than $0.4 \%$ were needed to inhibit the growth of some microorganisms, including L. monocytogenes, E. coli, and $S$. aureus. ${ }^{25}$ Gallic acid which also contributed to antibacterial activity of PABE is a basic constituent of many other plant extracts. Tea extracts which contain gallic acid and catechins proved to be effective against H. pylori without affecting beneficial bacteria. ${ }^{26}$ These data suggest that PABE or its components like gallic acid and catechin could not only be efficient against MDR A. baumannii, but they could also be used in combination with probiotic bacteria. In our research the tested in vitro concentrations of basic PABE components that showed antibacterial activity against $A$. baumannii were at least three orders of the magnitude higher than the concentration of substances found in plasma of patients after oral ingestion of the same quantity of PBE. ${ }^{15,16}$ Therefore, the concern exists that the concentration of the bioactive substances in plasma of patients would not be high enough to treat bacteraemia, but since $A$. baumannii causes also skin and wound infections, ${ }^{27,28,29}$ application of PABE in sufficient concentration in such cases is certainly possible. Except investigated basic substances, proanthocyanidins that were determined in PABE could have also contributed to the antibacterial activity. In grape seeds, proanthocyanidins were determined as active antibacterial agents toward 10 different pathogenic Gram-positive and Gram-negative bacterial strains. ${ }^{30}$ Plant-derived proanthocyanidins may inhibit the growth of pathogenic bacteria by binding strongly to proteins at bacterial cell surfaces. ${ }^{31}$

In this research we revealed that PABE at the concentration $200 \mathrm{mg} \mathrm{ml}^{-1}$ showed bactericidal activity against two MDR clinical isolates of $A$. baumannii belonging to EU clone I and II and antibacterial activity at lower concentrations, in vitro. This finding suggests that $\mathrm{PABE}$ and its components could potentially find an application in treatment of MDR A. baumannii-infected patients.

Acknowledgements. This research was supported by the Croatian Ministry of Science, Education and Sports.

\section{REFERENCES}

1. A. Maimoona, I. Naeem, Z. Saddiqe, and K. Jameel, J. Ethnopharmacol. 133 (2011) 261-277.

2. P. Rohdewald P, Int. J. Clin. Pharmacol. Ther. 40 (2002) 158-168.

3. M. S. Ramirez, M. Don, A. K. Merkier, A. J. S. Bistue, A. Zorreguieta, D. Centron, and M. E. Tolmasky, J. Clin. Microbiol. 48 (2010) 1488-1490.
4. F. Perez, A. Hujer, K. Hujer, B. K. Decker, P. N. Rather, and R. A. Bonomo, Antimicrob. Agents Ch. 51 (2007) 3471-3484.

5. L. Malone and D. H Kwon, Int. J. Antimicrob. Ag. 41 (2013) 70-74.

6. I. Roca, P. Espinal, X. Vila-Farres, and J. Vila, Front. Microbiol. 3 (2012) 1-30.

7. I. Goić-Barišić, B. Bedenić, M. Tonkić, A. Novak, S. Katić, S. Kalenić, V. Punda-Polić, and K. J Towner, J. Clin. Microbiol. 47 (2009) 3348-3349.

8. I. Goić-Barišić, K. J. Towner, A. Kovačić, K. Sisko-Kraljević, M. Tonkić, A. Novak, and V. Punda-Polić, J. Hosp. Infect. 77 (2011) 368-369.

9. H. J. Doughari, P.A. Ndakidemi, I. S. Human, and S. Benade, Microbes Environ. 26 (2011) 101-111.

10. L. J. Porter, L. N. Stich, and B. G. Chan, Phytochemistry 25 (1986) 223-230.

11. CLSI - Clinical and Laboratory Standards Institute (2007) Performance standards for antimicrobial susceptibility testing, $17^{\text {th }}$ informational supplement, M100-S17. CLSI, Wayne, PA.

12. I. Goić-Barišić and V. Kaliterna, Med. Glas. 8 (2011) 312-313.

13. M. A. C. Torras, C. A. Faura, F. Schönlau, and P. Rohdewald, Phytother. Res. 19 (2005) 647-648.

14. P. Rohdewald and W. Beil, Phytother. Res. 22 (2008) 685-688.

15. T. Grimm, Z. Chovanova, J. Muchova, K. Sumegova, A. Liptakova, Z. Durackova, and P. Hogger, J. Inflam. 3 (2006) 1.

16. T. Grimm, R. Skrabala, Z. Chovanova, J. Muchova, K. Sumegova, A. Liptakova, Z. Durackova, and P. Hogger, BMC Clin. Pharmacol. 3 (2006) 4.

17. D. J. Fitzgerald, M. Stratford, M. J. Gasson, and A. Narbad, J. Agricult. Food Chem. 53 (2005) 1769-1775.

18. D. J. Fitzgerald, M. Stratford, M. J. Gasson, J. Ueckert, A. Bos, and A. Narbad, J. Appl. Microbiol. 97 (2004) 104-113.

19. G. P. Yemis, F. Pagotto, S. Bach, and P. Delaquis, J. Food Protect. 74 (2011) 2062-2069.

20. S. Muthuswamy, and H. P. V. Rupasinghe, J. Food Agricult. Environ. 5 (2007) 81-85.

21. OM Vandeputte, M. Kiendrebeogo, S. Rajaonson, B. Diallo, A. Mol, M. El Jaziri, and M. Baucher, Appl. Environ. Microbiol. 76 (2010) 243-253.

22. Y. S. Lee, C. H. Han, S. H. Kang, S. J. Lee, S. W. Kim, O. R. Shin, Y. C. Sim, S. J. Lee, and Y. H. Cho, Int. J. Urol. 12 (2005) 383-389.

23. R. X. Qin, K. K. Xiao, B. Li, W. W. Jiang, W. Peng, J. Zheng, and H. Zhou, Int. J. Mol. Sci. 14 (2013) 1802-1821.

24. J. W. Betts, S. M. Kelly, and S. J. Haswell, Int. J. Antimicrob. Ag. 38 (2011) 421-425.

25. M. P. Almajano, R. Carbo, M. E. Delgado, and M. H. Gordon, J. Food Sci. 72 (2007) C258-263.

26. C. Ankolekar, D. Johnson, M. D. Pinto, K. Johnson, R. Labbe, and K. Shetty, J. Med. Food 14 (2011) 1321-1329.

27. C. Bachmeyer, N. Landgraf, F. Cordier, P. Lemaitre, and L. Blum, Clin. Exp. Dermatol. 30 (2005) 256-258.

28. B. Corradino, F. Toia, S. di Lorenzo, A. Cordova, and F. Moschella, Int. J. Lower Extremity Wounds 9 (2010) 152-154.

29. B. La Scola, and D. Raoult, Emerg. Infect. Dis. 10 (2004) 1671-1673.

30. R. Mayer, G. Stecher, R. Wuerzner, R. C. Silva, T. Sultana, L. Trojer, I. Feuerstein, C. Krieg, G. Abel, M. Popp, O. Bobleter, and G. K. Bonn, J. Agric. Food Chem. 56 (2008) 6959-6966.

31. Z. $\mathrm{Xu}, \mathrm{P} . \mathrm{Du}, \mathrm{P} . \mathrm{Meiser}$, and J. Claus, Nat. Prod. Commun. 7 (2012) 381-388 